\title{
SEJARAH DAMPAK KAJIAN MADRASAH TERHADAP TRANSFORMASI INTELEKTUAL ISLAM MASA KLASIK
}

\author{
Asep Kurniawan \\ IAIN Syekh Nurjati Cirebon (asepqurniawan.ak@gmail.com)
}

\begin{abstract}
The establishment of Madrasah as an educational institution is not purely educational. There is a political and ideological motif behind the stand. This motivation has implications for the study of madrasah which is thick with the content of religious science of Sunni version especially fiqih. The knowledge is more likely to recycle and preserve the establishment of religious doctrines, and less encourage creative critical thinking as in the natural sciences. Considerable impact is the development of intellectual transformation and subsequent Islamic civilization that stagnated with the closing of the door of ijtihad and the dichotomism of Islamic scholars. A historical problem that leads to the decline of Islam.
\end{abstract}

Keywords: Madrasah, religious science, transformation, science, intelectuality

\begin{abstract}
Abstrak
Pendirian Madrasah sebagai institusi pendidikan tidak murni bermotif pendidikan. Ada motif politik dan ideologi dibalik pendiriannya. Motif ini berimplikasi kepada kajian madrasah yang kental dengan muatan ilmu-ilmu keagamaan versi sunni khususnya fiqih. Keilmuwan ini lebih cenderung kepada daur ulang dan pengawetan kemapanan doktrin-doktrin agama, serta kurang mendorong pemikiran kritis kreatif seperti pada ilmu-ilmu kealaman. Dampak yang cukup dirasakan adalah perkembangan transformasi intelektual dan peradaban Islam selanjutnya yang mengalami stagnasi dengan ditutupnya pintu ijtihad serta dikotomisme khasanah keilmuan Islam. Sebuah problem sejarah yang menghantarkan pada kemunduran Islam.
\end{abstract}

Kata Kunci: Madrasah, Ilmu agama, Transformasi, Keilmuan, Intelektual

\section{A. Pendahuluan}

Perkembangan pendidikan Islam secara kelembagaan dari zaman klasik Islam sampai dewasa ini nampaknya memiliki bentuk yang cukup bervariasi sesuai dengan kenyakinan dalam Islam yang mewajibkan menuntut ilmu. Dalam dunia Islam, lembaga-lembaga yang semula bersifat umum seperti kuttab, kegiatan di masjid, dan lembagalembaga yang mencerminkan kekhasan Islam selanjutnya berkembang menjadi lembaga yang khusus yakni madrasah. Madrasah menjadi pokok permasalahan tersendiri dan begitu menarik untuk dikupas secara khusus.
Hal ini karena, jika diamati lebih lanjut, ternyata tempat-tempat pendidikan di atas kecuali madrasah, bukan dipersiapkan khusus untuk pendidikan, misalnya masjid sebagai tempat pendidikan dalam perkembangannya dipertimbangkan, dikarenakan pendidikan di masjid dianggap telah mengganggu fungsi lembaga itu sebagai tempat ibadah, dengan berkembangnya ilmu pengetahuan, banyak ilmu yang tidak sepenuhnya diajarkan di masjid, dan timbulnya orientasi baru dalam penyelenggaraan pendidikan sehingga 
masjid tidak cocok untuk tempat pendidikan

Perkembangan

lembaga

pendidikan Islam sebagai wahana transformasi intelektual mengalami sejarahnya yang panjang. Pada masa awal perkembangannya, katakanlah dimulai sejak jaman Rasulullah SAW, pendidikan formal yang digulirkan secara sistematis dan baik belumlah terselenggara. Apa yang dapat diklaim sebagai aktivitas pendidikan sulit dipisahkan dari upaya-upaya yang berkaitan dengan dakwah islamiyah, yaitu penyebaran atau penanaman dasardasar kepercayaan dan ibadah Islam. Berkenaan dengan hal itu, pendidikan Islam yang semi formal - untuk tidak menyebut formal sepenuhnya - pada perkembangan selanjutnya di masa awal ini barangkali adalah proses pendidikan yang terjadi di rumah, dikenal dengan Dar al-Arqam. ${ }^{1}$

Cikal bakal pendidikan Islam dalam sebuah institusi baru dimulai pada masa kekhalifahan Umar bin Khattab. Secara khusus, sosok kharismatis tersebut mengirimkan 'petugas-petugas

\footnotetext{
${ }^{1}$ Dar al-Arqam merujuk pada rumah al-Arqam ibnu Abil Arqam, sebagai tempat Rasulullah saw mengajarkan pada para pengikutnya pokok-pokok ajaran Islam, serta membacakan ayat-ayat al-Qur'an. Disini sering dilakukan pengislaman orang-orang yang secara sukarela mengucapkan dua kalimat Syahadat. Lihat Ahmad Syalabi. Sejarah Pendidikan Islam. (Jakarta: Bulan Bintang, 1973), h. 58.
}

khusus' ke berbagai wilayah Islam untuk menjadi narasumber (guru) bagi masyarakat Islam di wilayah-wilayah tersebut. Para 'petugas khusus' ini biasanya bermukim di masjid dan mengajarkan tentang Islam kepada masyarakat melalui halaqah-halaqah dan majlis khusus untuk mempelajari agama dan terbuka untuk umum.

Di samping memiliki fungsi untuk tempat shalat berjamaah, masjid juga bermanfaat untuk kegiatan majlis ta'lim (pendidikan) dalam bentuk halaqah atau lingkaran belajar. Proses belajar di masjid dalam bentuk halaqah ini tetap dipertahankan di masa Khulafa alRasyidin, kekhalifahan Bani Ummayyah dan kekhalifahan Bani Abbasiyah. Pada masa terakhir ini, seiring dengan semakin besarnya minat atau jumlah kaum muslimin yang berkeinginan menuntut ilmu, masjid kemudian dilengkapi dengan khan (funduq atau penginapan), yakni asrama yang dibangun di samping masjid yang diperuntukkan terutama bagi para pendatang dari jauh. Mereka yang datang tidak punya cukup uang untuk menyewa penginapan diberi izin tinggal di komplek tanpa dipungut biaya. Tahap ini mencapai perkembangan yang sangat pesat pada abad ke-10. Dari sinilah muncul istilah masjid khan yang pada 
tahap perkembangan selanjutnya menjadi model bagi kemunculan madrasah. ${ }^{2}$ Madrasah dengan demikian menyatukan kelembagaan masjid biasa dengan masjid khan. Kompleks madrasah terdiri dari ruang belajar, ruang pondok, sebuah aula besar dan masjid. $^{3}$

Pada awalnya sistem pendidikan di masjid dengan madrasah adalah sama. Bahkan dari status bangunannya, antara masjid dan madrasah adalah sama-sama wakaf. Perbedaan mendasar antara pendidikan madrasah dan masjid terletak pada kontrol pendirinya. Pendidikan di masjid terbebas dari kontrol pendirinya sedangkan pendidikan madrasah selalu dikontrol oleh pendirinya. ${ }^{4}$

Demikianlah, lembaga pendidikan Islam yang sebelumnya banyak dilakukan di masjid-masjid ini terus mengalami penyesuaian. Madrasah terus diperluas dan berkembang sejalan dengan perkembangan zaman berikut ragam perubahan yang dipengaruhinya. Setidaknya ada dua faktor yang sangat berpengaruh bagi awal perkembangan madrasah. Pertama, perhatian dan peran aktif penguasa. Tidak bisa dipungkiri

\footnotetext{
${ }^{2}$ George Makdisi. The Rise of College: Institutions of Learning in Islam and West. (Edinburgh: Edinburgh University Press, 1981), h. 106-108

${ }^{3}$ Ibid, h. 27-28

${ }^{4}$ Ibid, h. 27.
}

bahwa keterlibatan pemerintah memiliki andil yang cukup besar bagi perkembangan dan kemajuannya. Kedua, perhatian yang besar dari para saudagar, ulama, dan elemen masyarakat lainnya. Tidak sedikit dari mereka yang mendirikan madrasah dengan model dan standar yang relatif sama dengan madrasah yang didirikan oleh para penguasa pada zamannya.

Ahmad Syalabi menjelaskan motivasi teknis perpindahan proses pendidikan Islam dari masjid ke madrasah. Ia mengemukakan bahwa perpindahan itu disebabkan oleh semakin tersubordinasinya fungsi murni masjid sebagai tempat shalat oleh kegiatan-kegiatan halaqah yang terus meningkat, dan mulai diterapkannya tradisi bahtsul masail dengan metode jadal (debat) yang mengutip pendapatnya Von Kremers dalam Kudha Bukhsh: Islamic Civilization, didorong pula oleh adanya alasan profesionalisasi bagi guru-guru yang menghabiskan waktunya untuk kegiatan mengajar. ${ }^{5}$ Dari sini dapat kita tangkap sebuah pemahaman bahwa munculnya madrasah merupakan upaya formalisasi pendidikan Islam, sesuai dengan kebutuhan umat saat itu yang membutuhkan adanya

${ }^{5}$ Ahmad Syalabi. Op cit, h. 106. 
tempat khusus bagi kegiatan belajar mengajar.

Sepanjang penelusuran tentang madrasah pada masa klasik ini, ${ }^{6}$ ternyata kemunculannya tidak semata-mata dilatarbelakangi oleh hal-hal yang bersifat academic oriented seperti yang dikemukakan oleh Ahmad Syalabi di atas, tetapi juga erat kaitannya dengan supremasi yang diberikan oleh satu otoritas paham keagamaan tertentu bagi cara dan seperti apa seharusnya pengembangan ilmu. Bagaimana proses ini terjadi, dan lantas apa saja yang dikaji oleh madrasah dalam perkembangannya saat ini? Dua persoalan ini yang menjadi stressing point dalam uraian tulisan ini. Selanjutnya, dari pembahasan diharapkan akan muncul pemahaman bersama terhadap proses historis pendidikan Islam sebagai bagian integral dari keseluruhan gerakan intelektual yang turut menentukan arah perkembangan intelektual Islam.

\section{B. Lahirnya Madrasah: Patronasi Paham Sunni}

Kajian sekitar munculnya madrasah di dunia Islam, banyak

\footnotetext{
${ }^{6}$ Masa klasik adalah masa yang terbentang antara tahun $650 \mathrm{M}-1250 \mathrm{M}$. Lihat Harun Nasution. Pembaharuan dalam Islam: Sejarah Pemikiran dan Gerakan. (Jakarta: Bulan Bintang, 1991), h. 13.
}

sejarawan pendidikan Islam yang berbeda pendapat. Ahmad Syalabi menyatakan bahwa madrasah yang mula-mula muncul di dunia Islam adalah Madrasah Nizhamiyah yang didirikan oleh Nizham al-Mulk, ${ }^{7}$ pada tahun 1065 7. Philip K. Hitti juga mengemukakan pendapat seperti itu. ${ }^{8}$ Berbeda dengan kedua sejarawan tersebut, al-Maqrizi, sebagaimana dikutip oleh Athiyah alAbrasyi, mengemukakan bahwa

${ }^{7}$ Nizham al-Mulk (bahasa Arab: نظام الملك), lahir 10 April 1018 - wafat 14 Oktober 1092 adalah seorang wazir atau perdana menteri Kesultanan Seljuk dan cendekiawan keturunan Persia. Nama aslinya adalah Abu Ali al-Husain bin Ali bin Ishaq bin al-Abbas atThusi ( أبو علي الحسين بن علي بن إسحاق بن العباس الطوسي). Ia menjabat wazir pada masa pemerintahan Alp Arslan dan Malik Syah I. Pada masa Nizham alMulk inilah aliran Asy'ariyah menjadi kuat berkembang karena dijadikan aliran resmi negara, dan keilmuan al-Ghazali mendapat dukungan penuh darinya. Ia memegang kekuasaan selama 20 tahun semenjak meninggalnya Alp Arslan pada tahun 1072. Nizham al-Mulk pernah ke Nisabur dan menuntut Ilmu pada ulama Madzhab Syafi'i Hibatullah al-Muwaffaq. Ayahnya adalah seorang pegawai pemerintahan Gaznawi di Tus, Khurasan. Ketika sebagian besar Khurasan jatuh ke tangan pasukan Salajikah di Gazna, Nizham al-Mulk bekerja pada sebuah kantor pemerintah Mahmud Gaznawi. Nizham al-Mulk juga dikenal berpaham Asy'ariyah dan mengusahakan penyebarannya melalui madrasah-madrasah di beberapa kota dalam wilayah Salajikah. Lihat Foltz, Richard. Iran in World History: New Oxford World History. (Oxford, UK: Oxford University Press, 2015), h. 64; Gustave E. Von Grunebaum, Katherine Watson, Classical Islam: A History, 600 A.D. to 1258 A.D. (Piscataway, New Jersey, United States: Aldine Transaction, 2005), h. 155; Darke, Hubert, ed. The Book of Government or Rules for Kings. (New York: Persian Heritage Foundation, 2002), h. ix-x; Josef W. Meri (2005). Medieval Islamic Civilization: An Encyclopedia. (Abingdon, United Kingdom: Routledge), h. 856.

8 Ahmad Syalabi, Ibid, h. 110; Philip K. Hitti. History of the Arab. (London: McMillan Press Ltd, 1974), h. 410. 
madrasah yang pertama kali didirikan adalah Madrasah al-Baihaqiyah pada akhir abad ke-4 H (abad ke-1 M). ${ }^{9}$ Penelitian lebih akhir dilakukan oleh Richard Bullet, ia menemukan bahwa ada 39 madrasah di wilayah Persia yang berkembang dua abad sebelum berdirinya Madrasah Nizhamiyah. Pendapat ini didukung oleh sejarawan pendidikan Islam lain, Naji Ma'ruf, yang mengatakan bahwa di Khurasan telah berkembang madrasah 165 tahun sebelum kemunculan Madrasah Nizhamiyah. Selanjutnya 'Abd al-'Al mengatakan, pada masa Sultan Mahmud al-Ghaznawi ${ }^{10}$ (berkuasa sekitar 388-421 H/998-1030 M) juga terdapat Madrasah Sa'idiyyah. ${ }^{11}$

9 Athiyah al-Abrasyi. Dasar-dasar Pokok Pendidikan Islam. (Jakarta: Bulan Bintang, 1993), h. 11

10 Yamīn-ud-Dawla Abul-Qāṣim Maḥmūd ibn Sebüktegīn lebih dikenal sebagai Mahmud dari Ghazni (November 971 - 30 April 1030), juga dikenal sebagai Mahmūd-i Zābulī adalah penguasa paling terkemuka dari Kerajaan Ghaznavida. Dia menaklukkan Iran bagian timur, Afganistan, dan barat laut India (Pakistan) dari tahun 997 sampai kematiannya pada tahun 1030. Mahmud mengubah bekas kota provinsi Ghazna menjadi ibu kota kaya dari sebuah kerajaan luas yang menutupi sebagian besar Afganistan saat ini, Iran timur, dan Pakistan, dengan menguasai kekayaan dari anak benua India. Lihat Kenneth Saunders. A Pageant of India. (Oxford, UK: Oxford University Press, 1947), h. 162; T.A. Heathcote. The Military in British India: The Development of British Forces in South Asia:1600-1947. (Manchester, UK: Manchester University Press, 1995), h. 6.

11 Azyumardi Azra. "Pendidikan Tinggi Islam: Sebuah Pengantar", dalam Charles Michael Stanton, Pendidikan Tinggi dalam Islam. (Jakarta: Logos, 1994), h. vi.
Suatu pekerjaan yang cenderung rumit untuk memastikan pendapat mana yang paling tepat dari beberapa pendapat di atas. Namun demikian, merujuk pada telaah Hanun Asrohah, secara eksplisit mengatakan bahwa Madrasah Nizhamiyah merupakan tonggak pertama dari bentuk madrasah. Kesimpulan ini didasari pada anggapannya bahwa terdapat kemungkinan penentuan Ahmad Syalabi dan Philip K. Hitti tersebut berangkat dari popularitas Madrasah Nizhamiyah yang terkenal dalam sejarah Islam, tidak terkecuali dalam ensiklopedi Islam. ${ }^{12}$ Dari beberapa madrasah yang disebut, Madrasah Nizhamiyah lebih mendapat perhatian.

Madrasah Nizhamiyah yang terkenal itu memiliki komitmen berpegang teguh pada doktrin Asy'ariyah dalam kalam (teologi) dan ajaran Syafi'i dalam fiqih. ${ }^{13}$ Madrasah Nizhamiyah didirikan oleh Nizham alMulk (w. 485 H/ 1092 M) yang pada mulanya hanya ada di kota Baghdad, ibu kota dan pusat pemerintahan Islam pada waktu itu. Madrasah Nizhamiyah ini didirikan dekat pinggir sungai Dijlah, di tengah-tengah pasar selasah di Baghdad.

12 Hanun Asrohah. Sejarah Pendidikan Islam. (Jakarta: Logos, 1999), h. 101.

${ }^{13}$ Azyumardi Azra. Jaringan Ulama: Timur Tengah dan Kepulauan Nusantara Abad XVII dan XVIII. (Bandung: Mizan, 1994), h. 62. 
Mulai dibangun pada tahun 457 H/1065

M dan selesai dibangun pada tahun 459

H (dua tahun lamanya baru selesai).

Selanjutnya dibangun lagi di beberapa tempat seperti, di Khurasan, Naisabur, Balkan dan Herat (Iran) ${ }^{14}$ Mosul, Basra dan Tibristan. Hal ini dilatarbelakangi, yaitu tatkala Nizham al-Mulk pergi ke suatu daerah dan menemukan orang yang berpengetahuan luas dan cukup dikenal, maka di tempat itu pula dibangun madrasah baru. Orang yang ditemuinya tersebut kemudian diangkat sebagai pengajar (Abdullah Idi dan Toto Suharto, 2006:22-23).

Nizham al-Mulk menetapkan untuk memberi gaji setiap bulan bagi setiap tenaga pengajar di madrasahmadrasah tersebut. Namun kebijaksanaan Nizham al-Mulk tentang gaji tersebut belum bisa diterima oleh para tenaga pengajar di Madrasah Nizhamiyah. Mereka lebih suka berkarya tanpa digaji namun dengan kesejahteraan hidup yang terjamin. Bagi para dosen, gagasan untuk menggaji guru pada masa itu dipandang sebagai suatu gagasan yang terlalu maju.

Di antara kekuatan Madrasah Nizhamiyah adalah bahwa madrasah tersebut mendapat pengakuan negara.

14 H.A.R. Gibb dan J.H. Kremers (ed,.), Shorter Encyclopedia of Islam. (Leiden: E.J. Brill, 1961), h. 303.
Madrasah Nizhamiyah telah mencatat nama-nama besar dan orang-orang yang mengabdikan dirinya sebagai tenaga pengajar. Di antara mereka adalah: Syekh Abu Ishaq asy-Syirazi, seorang faqih Baghdad, Syekh Abu Nasr asSabbagh, Abu Abdullah al-Tabari, Abu Muhammad asy-Syirazi, Abu Qasim alAlawi, at-Tibrizi, al-Qazwini, alFairuzabadi, Imam al-Haramain Abdul Ma'ali al-Juwaini, dan sang hujjatul Islam yaitu Imam al-Ghazali.

Kota-kota yang menjadi tempat berdirinya madrasah kemudian berkembang menjadi pusat-pusat studi keilmuan dan menjadi terkenal di dunia Islam pada masa itu. Para pelajar berdatangan dari berbagai daerah untuk mencari ilmu di madrasah-madrasah Nizhamiyah tersebut. Kesungguhan Nizham al-Mulk dalam membina madrasah-madrasah yang didirikannya itu tercermin pada kesediaannya menyisihkan waktunya untuk melakukan kunjungan ke madrasah-madrasah Nizhamiyah di berbagai kota tersebut. Disebutkan, bahwa dalam kesempatan kunjungannya tersebut, ia dengan penuh perhatian ikut menyimak dan mendengarkan kuliah-kuliah yang diberikan, sebagaimana ia juga kadang ikut mengemukakan pikiran-pikirannya di depan para pelajar di madrasah itu. 
Usaha Nizham al-Mulk mendirikan madrasah dan lembaga keagamaan lainnya mendapat dukungan dari ulama'-ulama' yang bermazhab Syafi'i dan dalam teologi beraliran Asy'ariyah. Para ulama tersebut bergembira dengan naiknya Nizham alMulk dan kebijaksanaannya mengembalikan nama baik ulama-ulama Asy'ariyah yang dikutuk oleh Perdana Menteri al-Kunduri pada masa Sultan Tugril Beq. Pada masa al-Kunduri aliran Asy'ariyah bersama dengan Rafidah dikutuk melalui mimbar-mimbar masjid, sehingga banyak ulama' yang melarikan diri, seperti Imam al-Haramain Abu Ma'ali al-Juwaini dan al-Qusyairi. Ulama-ulama baru mau kembali ke negeri mereka setelah Nizham al-Mulk menjadi perdana menteri dan melarang pengutukan Asy'ariyah di mimbarmimbar masjid.

Pendirian madrasah-madrasah ini sejalan dengan faham mu'tazilah yang mengalami kemunduran. Hal ini berawal dari sikap antipati masyarakat ketika itu terhadap doktrin-doktrin rasional Mu'tazilah yang lebih diakibatkan oleh implikasi peristiwa Mihna (inquisition,

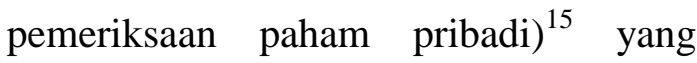

${ }^{15}$ Mihnah atau pengujian akidah bertitik tolak dari ajaran bahwa syirik adalah dosa besar yang tidak bisa diampuni. Mengakui al-Qur'an itu kekal adalah syirik karena itu bersifat hadits (baru). Lihat berdarah, dimana seseorang akan diancam dibunuh atau disiksa manakala mengingkari paham bahwa al-Qur'an itu hadits (baru). Disamping itu dari pihak penguasa sendiri, yakni pada masa kekuasaan al-Mutawakkil sekitar tahun $848 \mathrm{M}$, berusaha menghapus Mu’tazilah dan beralih mendukung gologan Sunni, kelompok mayoritas umat Islam saat itu.

Pendidirian Madrasah Nizamiyah selanjutnya bertujuan untuk menyebarkan pemikiran sunni untuk menghadapi tantangan dari pemikiran syiah dan menyediakan guru-guru sunni yang cakap untuk mengajarkan mazhab sunni dan menyebarkannya ke tempattempat lain serta membentuk kelompok pekerja sunni untuk berpartisipasi dalam mejalankan pemerintahan, khususnya dibidang peradilan dan manajemen. Sehingga dapat disimpulkan bahwa motivasi berdirinya madrasah dikarenakan adanya motivasi agama, ekonomi dan politik. Dengan berdirinya

Muhammad Qasim Zaman. Religion and Politics under the Early Abbasids: The Emergence of the Proto-Sunni Elite. (Netherlands: Brill, 1997), h. 106-112; Harun Nasution, op cit, h.54, dan 61-69; Michael Cooperson. Classical Arabic Biography: The Heirs of the Prophets in the Age of al-Ma'mūn. (Cambridge, UK: Cambridge University Press, 2000), h. 34-40; Marshall G. S. Hodgson. "The Venture of Islam: Conscience and History in a World Civilization", dalam The Classical Age of Islam. Vol. 1. (Chicago: University of Chicago Press, 1974), h. 389-391; Christopher Melchert. Ahmad ibn Hanbal: Makers of the Muslim World. (Oxford: Oneworld, 2006), h. 8-16. 
madrasah, maka pendidikan Islam memasuki periode baru yaitu pendidikan menjadi fungsi bagi negara dan sekolahsekolah dilembagakan untuk tujuan sektarian dan indoktrinasi politik.

Umat Islam terus bersikap antipati terhadap ilmu-ilmu rasional. Lambat laun rasionalisme pun tidak mendapat tempat lagi dalam kegiatan pendidikan Islam. Untuk selanjutnya aktivitas pendidikan Islam memprioritaskan pengajaran ilmu-ilmu keagamaan, khususnya pada bidang fiqih.

Demikianlah dengan kondisi sosial-politik saat itu, Madrasah Nizhamiyah di Bagdad yang arsiteknya adalah Sa'id al-Shafi ${ }^{16}$ itu pada perkembangan selanjutnya diikuti oleh berdirinya madrasah-madrasah lain, baik yang dibangun oleh Nizham al-Mulk sendiri maupun oleh penguasa-penguasa yang lainnya. Di Damaskus misalnya, penguasa Buruddin al-Zanky mengikuti jejak Nizham al-Mulk mendirikan madrasah di sana, yang akhirnya juga menyebar di kota-kota Syiria sampai ke desa-desa. Madrasah terbesar yang didirikannya adalah al-Nuriyah alKubra. Tindakan Nuruddin ini memotivasi penduduk Damaskus untuk turut mendirikan madrasah. Gubernurgubernur dan keluarga Buruddin juga

${ }^{16}$ Ahmad Syalabi, op cit, h. 112 mendirikan madrasah. Aktivitas ini berlangsung sampai abad ke-15. Pada abad ke-13 M terdapat 60 madrasah untuk Mazhab Syafi'i, 52 untuk Mazhab Hanafi, 4 madrasah Mazhab Maliki, 10 madrasah Mazhab Hambali. Shala al-Din al-Ayyubi juga memiliki reputasi besar sebagai pendiri madrasah. Pada masa ini menurut al-Maqrizi (wafat 845 H/ 1442 M), seperti dikutip Hillenbrand, telah berdiri 73 madrasah; 14 untuk madrasah Mazhab Syafi'i, 4 untuk Mazhab Maliki, 10 untuk Mazhab Hanafi, 3 untuk Mazhab Syafi'i dan Maliki, 6 untuk Mazhab Syafi'i dan Hanafi, 34 untuk empat mazhab, 2 buah untuk dar hadits dan lain-lain. ${ }^{17}$ Pendirian madrasahmadrasah ini juga dimotori oloeh komunitas dermawan yang punya kemampuan sosial dan ekonomi.

Perkembangan penting yang patut dicatat di sini adalah terjadinya pelenturan di bidang fiqih (tidak di bidang kalam) dalam penyelenggaraan madrasah yang sudah menjadi lembagalembaga pendidikan tipikal muslim saat itu. Hal ini terlihat dari sejumlah madrasah non-Mazhab Syafi'i sebagaimana tersebut di atas. Dari sini dapat kiranya diangkat satu tesis bahwa komunitas fiqih adalah komunitas yang

${ }^{17}$ Ibid, h. 112-129; Hanun Asrohah, op cit, h. 109111. 
toleran dalam peta perkembangan masyarakat Islam.

\section{Kurikulum Madrasah: Arah}

\section{Perkembangan Intelektual Islam}

Tercatat dalam sejarah, bahwa segera setelah wafatnya Rasulullah, persoalan yang pertama timbul dalam Islam adalah persoalan politik. Dari persoalan politik itu kemudian berkembang menjadi persoalan pemikiran. Bisa dikatakan, persoalan politik timbul mendahului perkembangan pemikiran, atau dengan kata lain masalah politik itu menjadi pendorong perkembangan pemikiran dalam Islam.

Latar belakang sejarah yang demikian itu, ternyata sangat mempengaruhi perkembangan pendidikan dan ilmu pengetahuan dalam Islam pada masa-masa selanjutnya. Dalam hal ini, dominasi kepentingan politik telah menentukan bentuk pendidikan dan corak ilmu pengetahuan yang dikembangkan dan diajarkan di dalamnya. Pendidikan Islam dalam pelajarannya, sangat dipengaruhi oleh dua arus pergumulan yaitu bidang politik dan pemikiran, yang saling berkaitan. Terutama sejak awal abad ke 3 Hijriah, ketika pertentangan antar pemikiran dalam Islam semakin tajam.
Salah satu bentuk pengaruh dari adanya pergumulan bidang politik dan pemikiran itu ialah dijumpainya tempattempat pendidikan yang khusus dan sekaligus merupakan ciri aliran pemikiran tertentu, sebagai contoh:

1. Ahli filsafat menggunakan: Dar alHikmah, al-Muntalinah, dan Warraqi'in.

2. Mutasawuf atau ahli sufi menggunakan al-Zawaya, al-Ribat, al-Masajid dan Halaqat al-Dzikir.

3. Syi'iyyin menggunakan Dar alHikmah, al-Masjid, dan pertemuan rahasia.

4. Mutakallimin atau ahli teologi menggunakan al-Masajid, alMaktabat, Hawarit, al Warraqin dan al-Muntadiyat.

Sedangkan madrasah, pada awalnya merupakan lembaga pendidikan yang mendukung ulama fiqh dan hadits.

Melalui kajian lebih dalam, tradisi keilmuan di madrasah ini dapat dilihat dari tiga hal yaitu segi transformasi, aliran dan kecenderungan politik pemerintahnya. Dalam hal transformasi akan dapat dilihat sejauh mana madrasah mempertahankan elemen pendidikan masjid di satu pihak dan menambahkan elemen-elemen baru di pihak lain.

Madrasah dapat diterima secara luas karena tujuan dan kurikulumnya 
yang sesuai dengan kecenderungan masyarakat ketika itu dan madrasah merupakan lembaga yang menjanjikan pekerjaan. Sebelum masa kebangkitan madrasah-madrasah, ilmu-ilmu yang diajarkan di beberapa sarana seperti kuttab, majlis, masjid dengan khalaqahnya dan khan itu berpusat pada pengajaran al-Qur'an sebagai pelajaran utama. Menurut Philip K. Hitti, alQur'an menjadi buku bacaan untuk pelajaran membaca, dan kemudian dipilih beberapa ayat untuk pelajaran menulis. ${ }^{18}$ Pelajaran baca tulis memang pelajaran dasar pada kuttab. Demikian pula pada sarana-sarana yang lain, alQur'an menjadi primadona pengajaran, yang kemudian diperluas dengan mengajarkan hadits, tafsir, ilmu bahasa seperti nahwu dan adab. Adapun pengajaran fiqih mulai mendapatkan tempatnya yang pasti di masjid melalui jami'-jami' yang dipimpin seorang syekh yang mengajarkan fiqih salah satu mazhab. ${ }^{19}$

Seorang tenaga pengajar di Nizhamiyah selalu dibantu oleh dua orang pelajar yang bertugas membaca dan menerangkan kembali kuliah yang telah diberikan kepada siswa yang ketinggalan (asistensi). Sistem belajar di

\footnotetext{
${ }^{18}$ Philip K. Hitti, op cit, h. 408

${ }^{19}$ Hanun Asrohah, op cit, h. 57.
}

Madrasah Nizhamiyah adalah: tenaga pengajar berdiri di depan ruang kelas menyajikan materi-materi kuliah, sementara para pelajar duduk dan mendengarkan di atas meja-meja kecil (rendah) yang disediakan. Kemudian dilanjutkan dengan dialog (tanya-jawab) antara guru dan para pelajar mengenai materi yang disajikan dalam suasana semangat keilmuan tinggi.

Nizham al-Mulk menetapkan untuk memberi gaji setiap bulan bagi setiap tenaga pengajar di madrasahmadrasah tersebut. Namun kebijaksanaan Nizham al-Mulk tentang gaji tersebut belum bisa diterima oleh para tenaga pengajar di Madrasah Nizhamiyah. Mereka lebih suka bekerja tanpa digaji namun dengan jaminan akan kesejahteraan hidupnya. Bagi para dosen gagasan untuk menggaji guru pada masa itu dipandang sebagai suatu gagasan yang terlalu maju.

Ketika madrasah muncul, alQur'an masih menjadi poros. Disiplindisiplin yang diperlukan untuk memahami dan menjelaskan al-Qur'an tumbuh sebagai bagian inti dari pengajaran yakni hadits, dan lalu tafsir. Hadits diajarkan dengan metode menghafal secara literal yang ratusan jumlahnya, adapun tafsir sangat bergantung dari kemampuan seorang 
syekh dalam mengajarkan metodemetode tafsir dan menjelaskan bahasa alQur'an. Ilmu retorika juga mendapat perhatian di samping juga pengetahuan sejarah dan geografi serta kesadaran umum tentang sistem pemerintahan dan sistem sosial. $^{20}$ Bagaimanapun, ilmuilmu yang disebut terakhir ini tidaklah begitu menarik dibandingkan kajian alQur'an dan Hadits.

Pada perkembangan selanjutnya fiqih mendapat tempat dalam kurikulum madrasah sebagai satu bidang kajian khusus dalam mazhab tertentu, di mana ilmu-ilmu lain berfungsi sebagai prasyaratnya. Tradisi keilmuan di madrasah ini dapat dilihat dari tiga aspek. Pertama, aspek transformasi madrasah dilihat dari sisi keilmuan, ilmu yang diajarkan di madrasah masih merupakan kelanjutan dari yang diselenggarakan di masjid. Kedua, aspek aliran agama. Madrasah merupakan lembaga sunni atau aliran fiqh. Apalagi metode yang dominan di madrasah adalah iqra' (ceramah) dan imla' (dikte) sehingga lebih merangsang budaya menghafal dari pada memahami. Ketiga, aspek politik pemerintah. Dari sudut keilmuan, keterlibatan pemerintah dalam madrasah hanya kepada ilmu yang mendukung satu mazhab yaitu mazhab

${ }^{20}$ Charles Michael Stanton, op cit, h. 55. syafi'i dari empat mazhab. Situasi ini menandai bahwa orientasi sunni secara umum merupakan kecenderungan rakyat atau kehendak sejarah.

Pendidikan serba fiqih adalah ciri yang menonjol dalam pendidikan Sunni muslim abad ke-11. Sebagaimana yang terungkap dalam sejarah, pola pendidikan semacam ini terus berlanjut dari abad ke abad. Jadi tidaklah berlebihan jika dikatakan bahwa Madrasah Nizhamiyah benar-benar menjadi model pendidikan madrasah pada masa klasik dan pertengahan Islam.

George Makdisi mencatat bidang studi usul fiqih atau prinsip-prinsip, sumber-sumber dan metodologi hukum Islam merupakan salah satu bidang yang pasti dalam kurikulum madrasah. ${ }^{21} \mathrm{Di}$ samping ilmu-ilmu tersebut, cabangcabang ilmu agama yang lain, seperti akhlaq, sangat mungkin sekali diajarkan di situ. Alasannya adalah bahwa setiap muslim wajib, fard al-'ain, mempelajari ilmu-ilmu tersebut. Imam al-Ghazali menekankan pentingnya kewajiban ini dalam karyanya Ihya al-'Ulum al-Din. Masuk akal bahwa al-Ghazali mengalamatkan kewajiban belajar kepada siswa-siswanya di Baghdad karena dia menulis beberapa bukunya sambil mengajar di madrasah itu. Masuk

${ }^{21}$ George Makdisi, op cit, h. 80. 
akal juga bahwa cabang-cabang ilmu agama yang lain, seperti nahwu, sharaf, adab (literature) juga disajikan di situ meskipun ilmu-ilmu itu hanya sebagai pelengkap.

Menurut Charles Michael Stanton, teologi dan filsafat tidak tumbuh sebagai bagian dari kurikulum pendidikan tinggi formal (madrasah) sebab figur muslim yang saleh adalah yang menerima sepenuhnya ajaran-ajaran Islam seperti dinyatakan dalam al-Qur'an dan percaya bahwa semua pengetahuan yang penting terdapat dalam al-Qur'an. Selanjutnya Stanton menyebutkan bahwa studi di bidang teologi dan filsafat ini dilakukan secara pribadi dalam pusat-pusat pendidikan non-formal, sangat sedikit tulisan para ahli muslim di bidang ini masuk pada kurikulum madrasah. ${ }^{22}$

Ilmu-ilmu seperti matematika, logika, astronomi, zoology, botani, antropologi dan psikologi memang ada tercatat dalam cakupan kurikulum pada abad ke-10. Misalnya catatan yang bersumber pada Ikhwan al-Shafa', suatu persaudaraan sufi yang mengabdikan diri bagi peningkatan pendidikan di dunia Islam, mencatat disiplin-disiplin ilmu tersebut. Namun, menurut Stanton ilmuilmu yang dikatagorikan oleh Ikhwan alShafa' ke dalam kelompok ilmu-ilmu

${ }^{22}$ Charles Michael Stanton, op cit, h. 54. filosofis itu bukan merupakan bagian dari pendidikan yang ditawarkan di madrasah, lebih-lebih di masjid.

Ketiadaan nuansa profan yang jelas dalam konstruksi kurikulum madrasah di masa klasik ini dipertegas oleh sejarawan masa kini, yakni Azyumardi Azra. Menurutnya kemajuan peradaban Islam masa klasik sebelum khalifah al-Ma'mun yang ditandai dengan pesatnya sains dan penerjemahan buku-buku filsafat Yunani hampir bisa dipastikan bukan muncul dari madrasah. Kemajuan sains lebih merupakan hasil dari individu-individu ilmuwan muslim yang didorong oleh semangat scientific inquiry melakukan ijtihad, namun jelaslah bukan dimaksudkan sebagai sebuah legitimasi penggunaan akal seluas-luasnya. Ia lebih berarti pemberian penafsiran baru yang tetap berada pada wilayah doktrin yang mapan dalam faham Sunni yang menempatkan akal di bawah wahyu.

Pada masa ini, peran ijtihad pun sebenarnya nampak menyempit dan akhirnya lenyap. Ini terjadi menurut Achmad Jainuri ketika fiqih muncul sebagai sistem hukum Islam dan adanya anggapan bahwa kebutuhan pengembangan prinsip baru dianggap sudah tidak ada. Gejala inilah yang kemudian dikenal dalam sejarah 
jurisprudensi Islam sebagai tertutupnya pintu ijtihad yang diyakini kaum muslimin sejak abad ke-4 $\mathrm{H}^{23}$

Mengapa sebenarnya ilmu-ilmu agama ini mengedepankan dalam konstruksi kurikulum madrasah, sementara ilmu-ilmu non-agama (profan) khususnya ilmu-ilmu alam dan eksakta merupakan akar pengembangan sains dan teknologi - sejak awal perkembangan madrasah berada pada posisi marjinal? Ahmad Syalabi memberikan jawabannya bahwa pembahasan tentang pendidikan Islam tentu menyiratkan pengetahuan agama sebagai kontennya, di samping adanya kepentingan penguasa untuk berkhidmat pada ajaran Sunni yang dianggap paling benar. $^{24}$

Madrasah merupakan babak baru dalam pendidikan Islam karena pemerintah telah ikut terlibat di dalamnya. Keterlibatan tersebut sangat erat kaitannya dengan tujuan pemerintah, sehingga pendidikan merupakan bagian dari institusi pemerintah untuk mencapai tujuan-tujuannya. Dari sudut keilmuan, keterlibatan pemerintah dalam Madrasah Nizhamiyah telah mengarahkan

23 Achmad Jainuri. "Landasan Teologi Gerakan Pembaharuan Islam", dalam Jurnal Ilmu dan Kebudayaan Ulumul Qur'an, Nomor 3 Vol. VI, tahun 1995.

${ }^{24}$ Ahmad Syalabi, op cit, h. 109. madrasah hanya kepada ilmu yang mendukung satu mazhab dari empat madzhab ini dengan mengandaikan bahwa orientasi Sunni secara umum memang merupakan kecenderungan rakyat atau kehendak sejarah.

Yang lebih penting lagi, karena pemilihan materi pelajaran memiliki kaitan dengan tujuan-tujuan politis, atau tujuan-tujuan sektarian, maka teknik penyampaiannya pun cenderung tertutup dan bersifat indoktrinasi sesuai dengan tradisi keilmuan yang diberikan di madrasah terfokus kepada pengajaran ilmu-ilmu agama dengan penekanan khusus pada bidang fiqh dan hadis. Karakteristik ilmu-ilmu tersebut, apalagi untuk kepentingan mempertahankan faham, tidak mungkin diajarkan dengan metode pengajaran yang terbuka yang dapat merangsang pengembangan ilmu pengetahuan. Metode yang menonjol dalam madrasah ialah metode ceramah dan dikte. Metode demikian memang sesuai dengan tabiat ahli fiqh dan ahli hadis yang selalu takut terhadap pengaruh lupa dan pencampuran lafadz yang menurut mereka akan berpengaruh besar terhadap hukum. Di samping itu "ilmu agama" lebih merangsang siswa kepada budaya menghafal dari pada memahami. 
Dengan kata lain, ideologisasi dari materi-materi pelajaran ini tidak memberikan kesempatan untuk mengembangkan cara berfikir yang bebas. Sejalan dengan itu, banyak diantara peserta didik di madrasah terpaksa beralih madzhab agar memperoleh keuntungan dari pendidikan madrasah yang bersifat demikian. Dilihat dari segi ini, pendidikan di madrasah merupakan satu kemunduran dibanding di masjid. Di masjid seseorang memiliki kebebasan untuk mengeluarkan pendapat dan memilih halaqah sesuai dengan minatnya, tanpa terkena sangsi.

Demikian perwajahan konstruksi kajian madrasah yang tumbuh pada masa klasik selama kurang lebih satu setengah abad lamanya sejak berdirinya Madrasah Nizhamiyah yang dianggap peletak utama madrasah sebagai pendidikan tipikal Islam saat itu. Dalam jangka waktu yang tidak sebentar itu, tentu madrasah merupakan agen utama dalam mempengaruhi arah perkembangan intelektual Islam yang sangat bercorak ilmu agama konvensional itu dan dicurigai memunculkan stagnasi intelektual serta khasanah keilmuan Islam yang turut membawa kemunduran peradaban Islam.

Kemandekan dalam intelektual itu telihat dalam suatu pernyataan "pintu ijtihad telah tertutup" dan ajaran menyatakan bahwa "dunia adalah penjara bagi kaum muslimin”. Penutupan pintu ijtihad ini telah menyumbat pemikiran yang orisinal dan bebas serta membawa pada kemacetan umum pada aspek ilmu hukum dan intelektual. Dalam bidang fiqih yang berkembang adalah tradisi taklid buta dan menganggap kitab-kitab fiqih lama sebagai sesuatu yang sudah baku dan harus diikuti dengan apa adanya. Kebiasaan menulis dengan penulisan karya-karya asli tidak lagi ditemukan. Tradisi yang berkembang adalah hanya memberi komentar-komentar dari bukubuku lama. Tidak seperti halnya yang terjadi sebelumnya, misalnya Fakhruddin al-Razi menulis sebuah komentar tentang karangan Ibn Sina, akan tetapi dia tetap membuat karyanya yang independen. ${ }^{25}$

Kemunduran yang lain terutama adalah pada pendidikan yang nampak jelas dengan sedikitnya materi kurikulum dan mata pelajaran. Selain itu juga menyempitnya bidang ilmu pengetahuan umum dan terbatasnya ilmu-ilmu agama. Kemudian waktu yang diperlukan dalam menempuh studi juga relatif singkat, sehingga mengakibatkan

\footnotetext{
${ }^{25}$ Samsul Nizar. editor. Sejarah Pendidikan Islam. (Jakarta: Kencana Prenada Media Group, 2009), h. 191-192.
} 
kurangnya pendalaman materi pelajaran yang diterima. Hal ini menjadikan perkembangan ilmu pengetahuan mandek dan mengalami kemorosotan. Madrasah-madrasah yang berkembang diwarnai oleh khalaqah-khalaqah dan zawiat-zawiat sufi, karya-karya sufi dimasukkan ke dalam kurikulum yang formal, dan kurikulum akademis terdiri dari hampir seluruh buku-buku tentang sufi. $^{26}$

Kenyataan seperti ini tentu merupakan kritikan utama kajian madrasah pada transformasi intelektual masa-masa setelahnya, terutama pada masa pembaharuan yang tidak pada porsinya dibicarakan pada tulisan ini. Walau begitu, satu apresiasi yang bijak apabila tetap menganggap bahwa perwajahan madrasah di masa klasik ini hadir sesuai dengan kondisi zaman saat itu. Sebagai mata rantai sejarah tentunya memiliki kontribusi bagi perkembangan intelektual selanjutnya.

\section{Penutup}

Tumbuh dan berkembangnya madrasah di bawah patronasi Sunni pada masa klasik jika dipandang semata-mata dari sudut keagamaan, maka terlihat mengandung implikasi yang bersifat positif, yaitu terjadinya pemantapan fiqih sebagai salah satu inti Islam sehingga lebih menjamin transmisi ilmu ini bagi generasi-generasi berikutnya. Namun demikian, jika dilihat dalam perspektif lebih luas, supremasi ilmu-ilmu agama memiliki dampak substansi, tidak saja pada perkembangan ilmu dalam Islam tetapi juga peradaban Islam secara keseluruhan. Dalam konteks ini terjadi dualisme hirarkis ilmu, ilmu agama lebih utama dari ilmu profan. Fenomena ini kemudian dipandang sebagai problem ilmu dalam peradaban Islam yang tidak mudah untuk dicairkan.

Dalam plus-minusnya perkembangan madrasah di masa klasik ini, kiranya proses historis yang menggiring perkembangan madrasah ketika itu dijadikan sebagai cermin yang seyogyanya menimbulkan refleksi, pada gilirannya menimbulkan upaya-upaya kreatif dalam rangka upaya pembaharuan lembaga-lembaga pendidikan Islam pada masa kini dan pada masa yang akan datang.

\section{Daftar Pustaka}

Abrasyi, Athiyah al-. (1993). Dasardasar Pokok Pendidikan Islam. Jakarta: Bulan Bintang.

Asrohah, Hanun. (1999). Sejarah Pendidikan Islam. Jakarta: Logos.

${ }^{26} \mathrm{Ibid}$ 
Azra, Azyumardi. (1994). "Pendidikan Tinggi Islam: Sebuah Pengantar", dalam Charles Michael Stanton. Pendidikan Tinggi dalam Islam. Jakarta: Logos.

(1994). Jaringan Ulama: Timur Tengah dan Kepulauan Nusantara Abad XVII dan XVIII. Bandung: Mizan.

Cooperson, Michael. (2000). Classical Arabic Biography: The Heirs of the Prophets in the Age of alMa'mun. Cambridge, UK: Cambridge University Press.

Darke, Hubert, ed. (2002). The Book of Government or Rules for Kings. New York: Persian Heritage Foundation

Foltz, Richard. (2015). Iran in World History: New Oxford World History. Oxford, UK: Oxford University Press.

Gibb, H.A.R. dan J.H. Kremers (ed,.). (1961). Shorter Encyclopedia of Islam. Leiden: E.J. Brill.

Grunebaum, Gustave E. Von, Katherine Watson, (2005). Classical Islam: A History, 600 A.D. to 1258 A.D. Piscataway, New Jersey, United States: Aldine Transaction

Heathcote, T.A. 1995. The Military in British India: The Development of British Forces in South Asia: 1600-1947. Manchester, UK: Manchester University Press.

Hitti, Philip K. (1974). History of the Arab. London: McMillan Press Ltd.
Hodgson, Marshall G. S. (1974) "The Venture of Islam: Conscience and History in a World Civilization", dalam The Classical Age of Islam. Vol. 1. Chicago: University of Chicago Press.

Idi, Abdullah dan Toto Suharto. (2006). Revitalisasi Pendidikan Islam. Yogyakarta: Tiara Wacana.

Jainuri, Achmad. "Landasan Teologi Gerakan Pembaharuan Islam", dalam Jurnal Ilmu dan Kebudayaan Ulumul Qur'an, Nomor 3 Vol. VI, tahun 1995.

Makdisi, George. (1981). The Rise of College: Institutions of Learning in Islam and West. Edinburgh: Edinburgh University Press.

Melchert, Christopher. (2006). Ahmad ibn Hanbal: Makers of the Muslim World. Oxford: Oneworld.

Meri, Josef, W. (2005). Medieval Islamic Civilization: An Encyclopedia. Abingdon, United Kingdom: Routledge.

Nasution, Harun. 1991. Pembaharuan dalam Islam: Sejarah Pemikiran dan Gerakan. Jakarta: Bulan Bintang.

Nizar, Samsul. editor. (2009). Sejarah Pendidikan Islam. Jakarta: Kencana Prenada Media Group.

Saunders, Kenneth. (1947). A Pageant of India. Oxford, UK: Oxford University Press.

Syalabi, Ahmad. (1973). Sejarah Pendidikan Islam. Jakarta: Bulan Bintang. 